Freyja Cox Jensen, Dana L. Key, and Emma Whipday

\title{
The Disobedient Child: A Tudor Interlude in Performance
}

Filial impiety, domestic disorder, and a sizeable helping of song: the evening of 1 March 2019 saw all these presented to the audience gathered at Newcastle University, as we staged a reading of Thomas Ingelend's The Disobedient Child in order to explore the text and its performance possibilities before an audience of early modernists. ${ }^{i}$ As literary scholars and cultural historians, we are interested in the ways textual sources represent the lived experience of early modern people, particularly those who speak only quietly, if at all, in the documentary historical sources; we are also keen to understand the relationship between the depiction of those lived experiences and their reconstruction on the early modern stage, and the ways in which these might be received by audiences in our own time. Along with another Tudor interlude on which we have previously worked, Tom Tyler and His Wife (Davies; Key and Whipday), The Disobedient Child offers a window onto fantasies and anxieties about domestic relationships and household practices in the late-Tudor period through the format of a moralistic school play. ${ }^{\mathrm{ii}}$

Both plays are also significant precursors to the shrew narratives we see onstage in Shakespeare's Taming of the Shrew, the anonymous The Taming of a Shrew (potentially a source, memorial reconstruction, or adaptation), and Fletcher's sequel, The Tamer Tamed. The gender politics of both Tom Tyler and The Disobedient Child are thus crucial for a more complete understanding of the history of staged shrewishness in early modern England. Rarely does a purely 'imagined' or silently-read text reveal all its potential performative choices or challenges; therefore, in order to close-read these two Tudor interludes in relation to other early modern shrew plays, we need to understand how these texts function in performance.

In recent years, we have worked with both Tom Tyler and his Wife and The Disobedient Child to explore their dramaturgy, with an emphasis on comedy, violence, gender politics, stock figures, and moral messages. Here we explore our staged reading of The Disobedient Child, in which the narrative of a shrewish wife is subordinated to a tale of rebellion against parental authority, and the most significant relationship is between a father and a son, as the play enacts related themes of 'spare the rod, spoil the child' and the consequences of a lack of education on a wealthy young man.

Methodologically, we borrowed from the Read Not Dead model at Shakespeare's Globe: script-in-hand, a single group rehearsal, and limited, emblematic props and costumes. Building on Tiffany Stern's research, we also used "actors' parts" (comprising only the actor's own lines and short cues), rather than full scripts, and an onstage bookkeeper (Stern, chs 2 and 
Freyja Cox Jensen, Dana L. Key, and Emma Whipday

3). This challenging departure from the Read Not Dead model enabled us to explore how these methods inflect each actor's sense of their own character, the developing character relationships, and the relationship between actors and audience. We wanted, as far as possible, to avoid psychological realism, or anachronistic Stanislavskian approaches to character; we also wished to avoid realism in the performance of domestic violence, and so we used squeaking plastic truncheons for the beatings, in keeping with the play's comic register.

The use of actors' parts presented few textual or linguistic problems in rehearsal; indeed, we were struck by the extent to which this particular interlude offers few challenges in comparison with other texts with which we have worked. Unlike the majority of early modern playtexts, it does not feature large group scenes where the use of parts might prompt (potentially productive, or at least amusing) confusion or encourage several characters to speak at once, or in the wrong place (see Palfrey and Stern, Part III). With the exception of the final scene, in which the cast appears onstage but the speech is entirely addressed by the Perorator to the audience, scenes are almost entirely either two-handers, or self-contained soliloquies what Michael M. Wagoner terms 'solo scenes'.

Wagoner argues that solo scenes are 'a unique dramaturgical tool that melds character, speech, and scene into one unit... isolating a character from the rest of the play and constructing a character in that form' (97). Our performance demonstrated how the isolation of the characters from one another served to enhance the centrality of the relationship between the actor and the audience, as the audience becomes these characters' only auditor. Servant, for example, is self-consciously aware of the opportunity to relax with the audience, away from the demands of a capricious master:

For I by Saint George will tarry here still;

In all my life I was never so weary...

Now that I have rested so long in this place,

Homewarde again I will hie me apace. (sig. E2v)

The solo characters share at once a real and a fictional 'place' with the audience, in moments where the space and time of fictional and real worlds collide; these are points at which the actors' parts provide them with all the information they require to create this direct and spontaneous connection with the audience.

While the use of actors' parts thus reinforced the powerful actor-audience relationship in the solo scenes, the variable lengths of individual speeches in the duologues forced the actors to engage in active listening, even without the necessity of working out which cue was spoken 
Freyja Cox Jensen, Dana L. Key, and Emma Whipday

by which speaker. The unpredictable structure, and the impetus of the (mostly) iambic pentameter, meant that actors could not simply 'turn-take', waiting for their interlocutor to fall silent in order to speak; this enabled us to keep up the pace of the play, which had a tendency to feel lengthy owing to the 'set-piece' or 'academic composition' nature of some of the speeches. Indeed, during the longest of these, the greatest challenge for the actor waiting for her/his cue was to find something useful to do. In any actors' parts performance with minimal rehearsal, the listening actor is usually relatively static; quite apart from not wishing to detract from the speaking actor, the auditor, unaware of the details of the speech being delivered, is not 'in control' of the stage at that point, and does not want to make movements that might work against whatever the speaker has in mind; and the auditor always needs to listen closely in order to respond appropriately to what is being said. In this particular performance, the nature of the speeches - often long, moralising, and prolix, making reference to moral sententiae from Cicero and other classical authorities - meant there was little to which the silent actor could usefully respond in a physical way, and the wait for the cue often felt like it lasted an uncomfortably long time. iii This was something upon which some audience members remarked in passing, but it was a problem more acutely perceived by the actors, unaccustomed to the performance of early modern oratory in the academic tradition, and more used to slicker and faster-paced dialogue.

This was even more the case for the actors waiting off-stage. In the absence of a full script, and unsure how long they would need to wait before their entrance, some actors were required to listen actively for more than half an hour. This, together with the effect of a long series of solo or two-handed scenes, had a somewhat disintegrative effect upon the cast dynamic. At no point (except in the final scene) was there a sense that this was a shared endeavour in any meaningful sense; not only did a number of the actors never appear on stage with one another, but the fact that many were simply functional roles - stock characters brought on for the sake of light relief, or characters created simply to narrate plot exposition - reinforced the sense that this is essentially a play with only three characters who are part of the 'story', while the others are there merely as padding.

Undoubtedly, this is at least partly the result of the play's evolution from Ravisius Textor's dialogue, Iuvenis, Pater, Uxor, which had been translated earlier in the century as Pater, Filius, et Uxor, or, The Prodigal Son; ${ }^{\text {iv }}$ Ingelend later refashioned it into an interlude probably intended for performance in schools. Our experience of performing the text demonstrates that The Disobedient Child, with its fragmented cast, laborious speech-making, and mixture of real and allegorical characters, represents a form of drama with which modern 
Freyja Cox Jensen, Dana L. Key, and Emma Whipday

actors are unfamiliar, as are modern audiences. The heavy-handed and explicit moral messages the play intends to convey to its audience also sit oddly with twenty-first century actors (and audiences) more used to pluralism than uniformity, to complexity than simplism; and yet the strangeness of the play to cast and audience enabled us to pay attention to its generic and formal specificities. Furthermore, our performance enabled us to engage with the ways in which the apparent simplicity of the play's moral is undermined by its sustained engagement with the problems and paradoxes inherent in the early modern ideology of a hierarchical household.

The Disobedient Child tells the story of a lazy son who defies his wealthy father, refusing to attend school and instead marrying without his father's permission. He spends his money on a profligate wedding feast: a pair of comic cooks lists the wide range of foodstuffs and meats required, while a tired servant bemoans the drinking, dancing, and disorder. His father, hearing of this, disinherits him and, lamenting that his son's 'Childhood with me so easily did slide / Full of pastime and delectation', offers advice to an imagined audience of parents about the dangers of overindulging their children (sig. B3r). All ends sadly for the boy, who finds that his new wife is violent, that he is unable to earn sufficient money through menial labour to keep them, and that his father, now that he is married, might be able to forgive him but is unwilling or unable to return him to the role of dependent son. A jubilant devil comes onstage to claim responsibility for the son's misbehaviour, and the play ends with a song, but without resolution.

The Disobedient Child, then, seems to be an elementary morality tale - a son disobeys his father and duly suffers for it. Yet the penalty he pays is far from straightforward: it might seem to be meted out by the wronged father, who retains the power to keep his money from his transgressing son, but the dramatic emphasis of the interlude is on the violence of the wife, who punishes the husband's disobedience towards a legitimate early modern authority figure by setting herself up as an illegitimate, and tyrannous, figure of alternative authority. Her shrewishness resides in treating her husband as an early modern wife might expect to be treated; because he has refused the role of son, she refuses to allow him to inhabit the role of husband.

Wife's first requests are eminently reasonable; when her husband spends all their money with no plans to earn more, she bids him sell wood that they might earn enough to eat. Yet once her instructions are obeyed, she strives for greater dominion over him; she orders him to wash clothes and fetch water, both activities associated with the early modern housewife. Finding his housewifely skills unsatisfactory, she 'knocks' him on the head until he lies on the ground, 'sore and beaten', before telling him: 
Freyja Cox Jensen, Dana L. Key, and Emma Whipday

\author{
Well, I perceive the time will away \\ And into the country to go I have promised. \\ Look therfore thou go not from hence today \\ Till home agayne I am returned. \\ Take heed, I say, this house thee retain, \\ And stir not for anything out of my door \\ Until that I come hither again, \\ As thou wilt be rewarded therefore. (sig. F2r)
}

This is a direct inversion of early modern gender conventions; as Henry Smith puts it in $A$ Preparative to Marriage:

We call the wife housewife, that is, house wife... to show that a good wife keeps her house. And therefore Paul biddeth Titus to exhort women that they be chaste, and keeping at home... as though home were chastity's keeper... So a wife should teach her feet, go not beyond the door. (sig.E7v-E8r)

This advice is idealised, and certainly did not reflect the lives of most early modern women, but it nonetheless suggests the imaginative importance of the threshold to the home in defining virtuous early modern wifedom. In insisting on visiting her gossips in the country while confining her husband to the home, Wife reverses the power of the threshold. A few decades later, Fletcher's Maria performs a similar tactic of husband-taming in The Tamer Tamed, insisting that Petruchio must be confined to his home due to plague. Like Maria, Wife challenges the spatial hierarchy of the home in order to undo the vertical hierarchy of household power dynamics.

The verticality of the idealised household hierarchy, as a microcosm of the wider commonwealth, is registered in Wife's language:

Why, doest thou rise against me, villain?

Take heed I scratch not out thy eyes twain. (sig. F1r)

Characterising his rebellion as 'rising', Wife takes for granted that she occupies a 'higher' position in the order of the household. Husband's response escalates the threat of violence, in an attempt to subordinate her:

Scratch an thou dare, for I have a knife;

Perchance I will rid thee of thy life. (sig. F1r)

However, Wife is not to be overawed, and responds: 
Freyja Cox Jensen, Dana L. Key, and Emma Whipday

Slay me with thy knife, thou shitten dastard?

Doest thou think to find me such a dissarde?

By Coxe bones I will make thy skin to rattle,

And the brains in thy skull more deeply to settle. (sig. F1r)

Wife's inclinations are not more violent than those of Husband; she is simply more skilled at acting upon these inclinations. In her oaths, foul language, and threats rooted in the language of physical violence (rather than in a fantasy of murder), she refuses to allow Husband to characterise her as a vulnerable and submissive subordinate or chattel.

Our audience questionnaire responses suggest - strikingly, but perhaps not unexpectedly - that the intensity of the domestic violence staged by the interlude caused significant discomfort, and that it was the element of the play that registered with them most powerfully. Many commented on the comic presentation of violence - that it was "performed as pantomime - with plastic cudgel'; 'oversized mallets clearly signalled comedy effect' - but these comments quickly shifted from amusement to anxiety:

It came across as comic, yet problematic that I found it comic.

It seemed unnatural to be laughing (a bit like a punch \& Judy show)

Funny at first, again because of props used and wife appeared on stage with the club sticking out of her pocket, but mainly surprising \& disturbing.

Comical at first, but then remembered Channel 4 documentary last week about male domestic violence victim

... seeing the son cowering was more upsetting.

... I did think about male victims of domestic violence.

These responses register a tension between the comic genre of the play, and the extent to which the play's language - focusing on the physical discomfort and youth of Husband, and hinting at the possibility of death - asks us to confront the violence as 'real'. 
Freyja Cox Jensen, Dana L. Key, and Emma Whipday

One audience member made the link between the 'surprising' sight of Wife beating Husband, and Husband's worries that at school he would be 'beaten by the schoolmaster': the play insistently interrogates the distinctions between legitimate violence, enacted by a figure of authority upon their subordinate, and illegitimate violence, operating in the opposite direction. The father is held up as culpable for failing to discipline his son sufficiently, and yet the son's fears about what he believes schoolboys suffer at the hands of the schoolmaster are disconcertingly graphic:

Diseases among them do grow apace.

For out of their back and side doth floe

Of very gory blood marvellous abundance,

And yet for all that is not suffered to go,

Till death be almost seen in their countinance.

Should I be content then thither to run

Where the blood from my breech thus shoulde spun? (sig. A4r)

This explicitly violent imagery clearly lingered in the mind of at least one of our audience members, calling into question violence as a means of reinforcing authority. The narrative of the interlude implies that the boy has made a trade-off: by avoiding the beatings of a schoolmaster, he has found himself at the mercy of his young wife's temper. Indeed, when similar physical violence is visited upon the husband by his wife, one audience member commented that 'reversing gender expectations took away any possible sting', while another noted 'I would have been disturbed if domestic violence went the other way. There was some nervous laughter.' The disconcerting humour of the scene, then, is rooted in the gender inversion; the upside-down nature of a wife overpowering, and ruling, her husband draws attention to its violation of expected gender roles. The play thus uses illegitimate violence to call into question the legitimate violence common to early modern households and schoolrooms, something that would prove the subject of considerable debate later in the Elizabethan and early-Stuart period (see Amussen,71-73).

This domestic topsy-turvydom is echoed elsewhere in the play through the 'set-piece' scenes and soliloquies already mentioned. In the Devil's speech, a long soliloquy where he claims responsibility for boy's disdain for learning, his filial disobedience, and his willful choice of an ill-advised marriage, he characterises himself as the head of a malign family:

The world is my Son, and I am his Father,

And also the flesh is a daughter of mine;

It is I alone that taught them to gather 
Freyja Cox Jensen, Dana L. Key, and Emma Whipday

Both gold and silver that is so fine.

Wherefore I suppose that they love me well,

And my commandments gladly obey,

That at the last then unto Hell

They may come all the ready way. (sig. F4v)

It is noteworthy that the personified 'children' of the Devil prove themselves more obedient than the child of the play's title; human sinners may make their way merrily to Hell, but in so doing, they reinforce domestic order, gathering gold and silver (which the play's protagonist fails to do) and obeying their father's commandments (which he refuses to do). The Devil is, in early modern terms, a more successful father than the careworn, moralistic Father at the centre of the play's action, for he is able to maintain and reinforce his household order. This impression of an oddly domestic Devil is reinforced when describes the crowding of his 'Palace' of Hell with sinners in the language of an inhospitable householder:

Not so much as my parlours, halls, and every chamber,

My porches, my galleries, and my court,

My entries, my kitchen, and my larder,

But with all maner people be filled throughout...

But now (I know) since I came hither

There is such a multitude at my gate,

That I must again repair down thither

After mine old manner and rate. (sig. F4v)

The Devil's description of a proliferation of distinct household spaces and boundaries - from the gate which the sinners cannot enter without the householders' admittance, to the hospitable halls and more private parlours and chambers, and the service spaces of kitchen and larder echoes the Wife's emphasis on the significance of domestic spaces, and is in keeping with a wider Elizabethan cultural emphasis on selective hospitality, withdrawal, and privacy, as part of the 'Great Rebuilding' of country houses (Hoskins; Orlin; Whipday, ch.3). Due to the crush of a multitude of sinners, the Devil is failing in his duties as a hospitable householder, which involved differentiating between the degrees of entertainment suitable to each guest; he is a victim of his own success in inviting sinners, and so, it is implied, the domestic disorder in the main plot leads inexorably to domestic disorder (and damnation) in the afterlife.

The Devil, then, is paralleled with the supposedly-virtuous authority figure - the wronged father - in his failings of domestic governance; and with the Priest, another 'solo' character, who similarly fails to govern his rebelliously absent clerk. The insertion of the figure of the devil, borrowed from the morality play genre, serves to reinforce the play's moral 
Freyja Cox Jensen, Dana L. Key, and Emma Whipday

message about how the lack of a sound and moral education leads a young man to a life filled with poor choices and their consequences. In warning against the perils of rebellion while staging failures of authority, The Disobedient Child is illustrative of a wider concern about authority in two central Tudor institutions: the household and the church. While the carnivalesque plot might superficially be contained by the moral of punishment through poverty and violence, order is never restored. Our performance, with its surprising moments of darkness and discomfort underlying the superficially boisterous comedy, showed us the sensitive staging and informed expectations required to bring the text to life, but it also gave us a glimpse of the moral and political complexity of this less-studied Tudor interlude.

\section{Works Cited}

Anon. Tom Tyler and His Wife. An Excellent Old Play, As It Was Printed and Acted About A Hundred Years Ago. Wing T1792. London: Francis Kirkman 1661.

Amussen, Susan Dwyer. “'Being stirred to much unquietness': violence and domestic violence in early modern England" Journal of Women's History 6 (1994): 70-89.

Bevington, David. From Mankind to Marlowe. Cambridge, M.A.: Harvard University Press, 1962.

Cartwright, Kent. Theatre and Humanism: English Drama in the Sixteenth Century. Cambridge: Cambridge University Press, 1999.

Chambers, E. K. The Elizabethan Stage. Oxford: Clarendon Press, 1923.

Davies, Callan. 'Tom Tyler and his Wife dir. by Emma Whipday'. Early Modern Women 12:2 (Spring, 2018): 212-218.

Hoskins, W. G. "The Rebuilding of Rural England 1570-1640". Past and Present 4 (November, 1953): 44-59.

Ingelend, Thomas. A Pretie and Mery New Enterlude: Called the Disobedient Child. STC 14085. London: Thomas Crolwell, 1570.

Key, Dana L., and Emma Whipday. "Tom Tyler and His Wife: Allegory, Satire, Shrews and Sheep". Research on Medieval and Renaissance Drama. Forthcoming, 2019.

Orlin, Lena Cowen. Locating Privacy in Tudor London. Oxford: Oxford University Press, 2007.

Palfrey, Simon, and Tiffany Stern. Shakespeare in Parts. Oxford: Oxford University Press, 2007. 
Freyja Cox Jensen, Dana L. Key, and Emma Whipday

Smith, Henry. A Preparative to Marriage. STC 22686. London: R. Field for Thomas Man, 1591.

Stern, Tiffany. Rehearsal from Shakespeare to Sheridan. Oxford: Oxford University Press, 2000.

Textor, Joannes Ravisius. Pater, Filius, et Uxor, or, The Prodigal Son. STC 20765.5. London: W. Rastell, 1530.

Wagoner, Michael M. "The Dramaturgical Space of Solo Scenes in Fletcher and Shakespeare, Or a Study of the Jailer's Daughter”. Shakespeare Bulletin 35.1 (Spring, 2017): 97-118.

Whipday, Emma. Shakespeare's Domestic Tragedies: Violence in the Early Modern Home. Cambridge: Cambridge University Press, 2019.

Wiggins, Martin and Richardson, Catherine. British Drama, 1533-1642: A Catalogue. Volume

\section{I, 1533-1566. Oxford: Oxford UP, 2012.}

\footnotetext{
${ }^{\mathrm{i}}$ Spelling has been modernised throughout, due to our practice of preparing the text for performance. Our reading was sponsored by MEMS (Medieval and Early Modern Studies) at Newcastle University and the Leverhulme Trust. We were joined by volunteer actors Oskar Cox Jensen, Esther Fearn, Tina Naples, and Emily Rowe. The event involved an enlightening talk on 'partial performance' of early Tudor drama by visiting speaker Jessica Winston.

ii The Disobedient Child was most probably the 'enterlude for boyes to handle \& to passe tyme at christinmas' entered in the Stationers' Register to its publisher Thomas Colwell in 1569 (Chambers III, 351). The original performance date of the play is unclear; Martin Wiggins suggests 1550, with limits of 1533-1553, based on an internal reference to a reigning king, with a revision to include a closing prayer to Queen Elizabeth I for its later publication (I, 220-2).

iii The long speeches, and their incorporation of Latin sententiae, reflect contemporary humanist pedagogical practices, whereby plays were translated, studied, and performed in schools. Such lengthy speeches were a means by which the pupils could demonstrate their oratorical skill (Cartwright, introduction and ch.2).

${ }^{\text {iv }}$ While only a fragment of the translated dialogue survives, the Latin titles clearly indicate the trio of father, son, and wife who are the characters at the centre of the story of The Disobedient Child (Chambers, III, 351; Bevington, 29).
} 